(C) 2017, THE AUTHORS. Published by FASS and Elsevier Inc. on behalf of the American Dairy Science Association ${ }^{\circledR}$.

This is an open access article under the CC BY-NC-ND license (http://creativecommons.org/licenses/by-nc-nd/3.0/).

\title{
Genome-wide association study for lactation persistency, female fertility, longevity, and lifetime profit index traits in Holstein dairy cattle
}

\author{
S. Nayeri, ${ }^{*}$ M. Sargolzaei,†‡ M. K. Abo-Ismail, ${ }^{\S}$ S. Miller,†\# F. Schenkel,† S. S. Moore,Il and P. Stothard*1 \\ *Department of Agricultural, Food and Nutritional Science, University of Alberta, Edmonton, Alberta, Canada, T6G 2P5 \\ †Centre for the Genetic Improvement of Livestock, University of Guelph, Ontario, Canada, N1G 2W1 \\ $\ddagger$ The Semex Alliance, Guelph, Ontario, Canada, N1H 6J2 \\ $\S$ Department of Animal and Poultry Production, Damanhour University, Damanhour, Egypt \\ \#Angus Genetics Inc., American Angus Association, St. Joseph, MO 64506 \\ $\|$ Agriculture and Food Innovation, Center for Animal Science, University of Queensland, St Lucia QLD 4072, Australia
}

\section{ABSTRACT}

Female fertility in Holstein cattle can decline when intense genetic selection is placed on milk production. One approach to improving fertility is to identify the genomic regions and variants affecting fertility traits and then incorporate this knowledge into selection decisions. The objectives of this study were to identify or refine the positions of the genomic regions associated with lactation persistency, female fertility traits (age at first service, cow first service to conception, heifer and cow nonreturn rates), longevity traits (herd life, indirect herd life, and direct herd life), and lifetime profit index in the North American Holstein dairy cattle population. A genome-wide association study was performed for each trait, using a single SNP (single nucleotide polymorphism) regression mixed linear model and imputed high-density panel (777k) genotypes. No associations were identified for fertility traits. Several peak regions were detected for lifetime profit index, lactation persistency, and longevity. The results overlap with previous findings and identify some novel regions for lactation persistency. Previously proposed causative and candidate genes supported by this work include DGAT1, GRINA, and CPSF1, whereas new candidate genes are SLC2A4RG and THRB. Thus, the chromosomal regions identified in this study not only confirm several previous findings but also highlight new regions that may contribute to genetic variation in lactation persistency and longevity-associated traits in dairy cattle.

Key words: longevity, genome-wide association study, lifetime profit index, fertility

Received July 22, 2016.

Accepted October 13, 2016

${ }^{1}$ Corresponding author: stothard@ualberta.ca

\section{INTRODUCTION}

Milk production and female fertility are 2 important traits that contribute to the profitability of the dairy industry (Boichard, 1990). Increasing milk production in dairy cattle has been a primary focus of genetic selection (Oltenacu and Algers, 2005). This selection has caused a decline in cow fertility because of the negative genetic correlation between fertility and milk production (Kadarmideen et al., 2000; Royal et al., 2002). It has been concluded that a combination of physiology, nutrition, genetic, and management strategies should be considered to provide a long-term improvement in fertility of high-producing dairy cows (Shook, 2006). Dairy breeding programs stand to improve the overall profitability of the industry through greater emphasis on durability, health, and fertility of cows (Kulak et al., 1997).

Genomic regions explaining variation in female fertility traits in cattle have been identified in several genome-wide association studies (GWAS) within a variety of breeds (Höglund et al., 2009; Pryce et al., 2010; Schulman et al., 2011; Sahana et al., 2011; Hawken et al., 2012; Peñagaricano et al., 2012; Minozzi et al., 2013; Höglund et al., 2015). Significant associations have been identified on several chromosomes for age at puberty (Hawken et al., 2012), cow nonreturn rate (Holmberg and Andersson-Eklund, 2006), pregnancy rate (Ashwell et al., 2004), and calving performance (Holmberg and Andersson-Eklund, 2006). More indepth analyses have identified several candidate genes associated with fertility traits such as pregnancy-associated plasma protein-A2 (PAPP2-A2) on chromosome 16 (associated with calving ease; Wickramasinghe et al., 2011) and calpastatin (CAST) on chromosome 7 (associated with fertility and longevity; Garcia et al., 2006) in dairy cattle (Minozzi et al., 2013).

The objective of this study was to detect genomic regions associated with several female fertility, longevity, and productivity traits in the North American Holstein 
population. Lifetime profit index (LPI), which reflects the relative profitability that can be expected during the lifetime of future daughters, was included in the analysis.

\section{MATERIALS AND METHODS}

\section{Animals and Data}

Animal Care and Use Committee approval was not obtained for this study because analyses were performed on existing data obtained under standard farm management from commercial dairy farmers and breeders. All dairy farmers in Canada must follow "The Code of Practice for the Care and Handling of Dairy Cattle" developed by the National Farm Animal Care Council of Canada (http://www.nfacc.ca/).

A population of Holstein bulls registered and used in North America was used in this study for 9 fertility- and profitability-related traits, including LPI, lactation persistency $(\mathbf{L P})$, herd life $(\mathbf{H L})$, indirect herd life (IHL), direct herd life (DHL), cow first service to conception (FSTCc), age at first service (AFS), heifer 56-d nonreturn rate (NRRh), and cow 56-d nonreturn rate (NRRc). The LPI consists of 3 main components: production (yield traits and milk components), durability (herd life, mammary system, feet and leg, dairy strength), and health and fertility (daughter fertility). The emphases given to components are $51 \%$ for production, $34 \%$ for durability, and $15 \%$ for health and fertility (trait definitions according to www.cdn.ca).

Lactation persistency is the average of expected milk yield of a bull's daughter at d 280 in lactation compared with that at d 60 in lactation. Herd life is directly measured as the survival (direct daughter survival) of each cow at 5 time points during their productive life; IHL is evaluated based on a combination of conformation traits, reproduction traits, and udder health. Cow first service to conception is the interval in days between the first service and conception. Age at first service is the age in days at which a heifer was inseminated for the first time. The NRRh and NRRc are the fraction of heifers and cows for which an insemination in a period of $56 \mathrm{~d}$ leads to conception.

The Canadian Dairy Network (CDN) provided genotypes, available pedigree information, and official evaluations for proven bulls born between 1956 and 2009. Individuals were genotyped using either the BovineSNP50K (50k) panel (44,369 SNP, 3,729 bulls) or the high-density (HD, 777k) SNP panel (774,605 SNP, 2,387 bulls; Illumina Inc., San Diego, CA). The 50k panel SNP genotypes were subjected to the standard quality control measures that are used by CDN (Wig- gans et al., 2009). Quality control was performed on the HD genotyping data using the snp1101 (Sargolzaei, 2014) software. This step excluded 116,619 SNP, including 46,433 SNP from a sex chromosome or misplaced SNP, 3,566 SNP with high Mendelian error rate $(>0.05), 6,446$ SNP with low call rate $(<0.9), 61,577$ SNP with low minor allele frequency $(<0.000001)$, and 90 SNP with excess heterozygosity ( $>0.15$; removing SNP that have a higher heterozygosity compared with expected heterozygosity from Hardy-Weinberg equilibrium, as explained by Wiggans et al., 2009). The purpose of choosing this threshold $(>0.15)$ was to exclude only the most outlying SNP in the data, eliminating possible genotyping errors (Wiggans et al., 2009). The number of SNP remaining for downstream imputation was 40,666 SNP for the 50k panel and 657,986 SNP for the HD panel.

The $3,72950 \mathrm{k}$ genotypes were imputed to the HD panel, using the 2,387 HD panel genotypes as the reference and the FImpute V2.2 software (Sargolzaei et al., 2014). After imputation, an additional quality control step was performed on the imputed data. A total of 55,817 SNP with minor allele frequency $<1 \%$ and 74 SNP with a Mendelian error rate $>5 \%$ ( 74 SNP) were excluded. After quality control, 602,095 SNP remained for use in the subsequent association analysis.

\section{Deregressed Proofs Calculation}

In this study, deregressed genetic evaluations of Holstein bulls were used as independent variables to test the association with the HD panel. In this genetic evaluation, a bull's published EBV is a weighted mean of his daughters' deviations (DD) and his parental average (PA; VanRaden et al., 2009). The deregressed bull proofs were computed by $\mathrm{CDN}$ as shown below (VanRaden et al., 2009):

$$
\begin{gathered}
D E_{p r g}=\frac{R e l_{E B V}}{1-\operatorname{Rel}_{E B V}}-\frac{R e l_{P A}}{1-\operatorname{Rel}_{P A}}, \\
R e l_{D D}=\frac{D E_{p r g}}{D E_{p r g}+1}, \\
D E B V=P A+\frac{(E B V-P A)}{R e l_{D D}},
\end{gathered}
$$

where $D E_{p r g}$ is the daughter equivalent from progeny information, and $R e l_{E B V}$ and $R e l_{P A}$ are the reliabilities of EBV and PA, respectively; $R e l_{D D}$ is the reliability of $\mathrm{DD}$, and $D E B V$ is the deregressed bull proof. 


\section{GWAS}

A single SNP regression mixed linear model implemented in the snp1101 software (Sargolzaei, 2014) was used for association analysis:

$$
\mathbf{y}=\mu \mathbf{1}+\alpha_{i} \mathbf{x}_{i}+\mathbf{Z a}+\mathbf{e}
$$

where $\mathbf{y}$ is a vector of deregressed proofs of the trait of interest; $\mu$ is the fixed mean effect and $\mathbf{1}$ is a vector of $1 \mathrm{~s} ; \alpha$ is the slope of the linear regression on the recoded genotype of the $i$ th SNP; $\mathbf{x}$ is a vector of original $A / B$ genotypes recoded as the number of $A$ alleles in the genotype of the $i$ th SNP; $\mathbf{a}$ is a vector of the random additive polygenic effects; $\mathbf{Z}$ is an incidence matrix for the additive polygenic effects; and $\mathbf{e}$ is a vector of random error terms.

The model assumptions are $a_{i}: a \sim N\left(0, \mathbf{G} \sigma_{a}^{2}\right)$, where $\mathbf{G}$ is the genomic relationship matrix (VanRaden, 2008), and $\sigma_{a}^{2}$ is the polygenic additive genetic variance; $e_{i}: e \sim N\left(0, \mathbf{R} \sigma_{e}^{2}\right)$, where $\sigma_{e}^{2}$ is the residual variance, and $\mathbf{R}$ is a diagonal matrix containing weights for the residual variance based on the reliabilities of the deregressed bull proofs (VanRaden, 2008).

To account for multiple tests, the false discovery rate (FDR) was controlled at 5\% and 1\% genome-wise levels to identify significant and highly significant associations, respectively. Quantile-quantile (Q-Q) plots and inflation factor $\lambda$ (Devlin and Roeder, 1999) were used to compare observed distributions of $-\log (P$-value $)$ to the expected distribution under the no association model for each trait.

\section{RESULTS AND DISCUSSION}

\section{LPI}

Selection for more profitable cows in the United States began with selection improvements in milk protein percentage in dairy cows (VanRaden, 2004). Later, traits were combined to form selection indices including yield traits, service sire calving ease, daughter calving ease, daughter pregnancy rate, and body conformation traits (VanRaden, 2004). Lifetime profit index includes most of the traits that affect the profitability of a dairy cow. Genome-wide association analysis for LPI identified 53 SNP significant at a genome-wise FDR 5\% (Table 1, Supplementary File S1; https://doi.org/10.3168/ jds.2016-11770). These significant SNP were located on BTA14 and 18 (Figure 1A). A Q-Q plot for LPI (Figure 2A) showed that deviation of the observed distribution of the $P$-values from the expected distribution under
Table 1. The number of significant SNP (5\% and $1 \%$ genome-wise false discovery rate, FDR) using single SNP mixed linear model on imputed BovineHD (777k; Illumina Inc., San Diego, CA) genotypes in Holstein dairy cattle

\begin{tabular}{lccc}
\hline & & \multicolumn{2}{c}{ No. of significant SNP } \\
\cline { 3 - 4 } Trait & Heritability $^{1}$ & 1\% FDR & 5\% FDR \\
\hline Lifetime profit index & 0.370 & 43 & 53 \\
Lactation persistency & 0.363 & 25 & 83 \\
Herd life & 0.097 & 197 & 510 \\
Indirect herd life & 0.097 & 59 & 140 \\
Direct herd life & 0.097 & 197 & 662 \\
\hline
\end{tabular}

${ }^{1}$ Heritability estimated and used by the Canadian Dairy Network in the Canadian national genetic evaluations.

the null hypothesis was minor and acceptable $\left(\lambda_{\text {median }}\right.$ $=1.0572$ ).

The most significant SNP for LPI were identified on BTA14 at 1.6 to $1.8 \mathrm{Mb}$. Our results indicate that several SNP in this region, including BovineHD1400000271: rs136792973, BovineHD1400000204: rs137727465 (within the CYHR1 gene), BovineHD1400000216: rs134432442 (within the CPSF1 gene), ARS-BFGLNGS-4939: rs109421300 (within the DGAT1 gene), and BovineHD1400000275: rs133271979 (within the GRINA gene), are located within the confidence intervals of previously identified QTL regions (Supplementary File S2; https://doi.org/10.3168/jds.2016-11770). The significant influence of a polymorphism (K232A polymorphism) in the DGAT1 gene on bovine milk production traits (milk yield, protein content, fat content, and fatty acid composition) has been shown in different studies (Grisart et al., 2002; Schennink et al., 2007, 2008; Conte et al., 2010). In addition, the CYHR1, CPSF1, and GRINA genes were reported to be associated with milk fat component in Danish and Chinese Holstein cattle (Buitenhuis et al., 2014; Jiang et al., 2014). These SNP also overlap with regions associated with clinical mastitis in Holstein dairy cattle (Supplementary File S2; https://doi.org/10.3168/jds.201611770; Sahana et al., 2013). We also identified a highly significant SNP (genome-wide FDR 1\%) in this study, Hapmap52798-ss46526455: rs41256919, which overlaps with the MAF1 gene on BTA14. The MAF1 gene has been shown to be associated with increased mammary gland milk protein synthetic capacity in lactating dairy cows (Sciascia et al., 2013).

Another highly significant SNP (BovineHD1400000188: rs134892687) on BTA14 was located within the Rho GTPase activating protein 39 ( $A R H$ GAP39) gene. This SNP and the assigned gene $(A R$ HGAP39) along with other SNP and genes (CYHR1, CPSF1, DGAT1, GRINA, SMPD5) were reported to be significantly associated with milk fat and fat com- 
ponent traits in Danish Holstein cattle (Buitenhuis et al., 2014). Additionally, in a GWAS study in Chinese Holstein cattle, several significant SNP, including those identified as significant in this study for LPI (ARSBFGL-NGS-4939; ARS-BFGL-NGS-107379, and ARSBFGL-NGS-57820) were reported to be associated with somatic cell score EBV (Wang et al., 2015). Those authors speculated that the gene linked to these SNP (ARHGAP39) is a candidate for mastitis susceptibility in Holsteins (Wang et al., 2015). Mastitis is the most costly disease associated with loss of milk production and increase in culling rates in dairy cattle (Nemcova et al., 2007). The overlap in results between this previous mastitis work and our LPI results could be due to the influence of these variants on mastitis and consequently LPI.

\section{LP}

The GWAS analysis for LP identified several genomic regions with highly significant SNP on BTA6, 13, 20, and 27 (Figure 1B). The total number of significant SNP was 83 after correcting for multiple testing at a genome-wise FDR of $5 \%$, with the highest number of significant SNP on BTA20 (Supplementary File S1; https://doi.org/10.3168/jds.2016-11770). The corresponding Q-Q plot of the observed $P$-values compared with the expected distribution (under the null hypothesis) is shown in Figure 2B. Only a minor and acceptable deviation was found $\left(\lambda_{\text {median }}=1.065\right)$.

Lactation persistency as a trait has been analyzed in several previous studies (Boichard et al., 2003; Harder et al., 2006; Kolbehdari et al., 2009). Some of the regions identified in our analysis overlap with the QTL regions that were reported previously. The most significant SNP on BTA6 in our GWAS were located at $88 \mathrm{Mb}$. This region overlaps with a QTL region on BTA6 (between markers DIK082 at $48 \mathrm{Mb} / 57.55 \mathrm{cM}$ and ILSTS097 at $64 \mathrm{Mb} / 72.43 \mathrm{cM}$ ) associated with persistency of milk yield, persistency of protein yield, and persistency of milk energy yield in German Holstein cattle (Harder et al., 2006).

The region on BTA6 at $88 \mathrm{Mb}$ in the present study was previously reported to be associated with SCS in Holstein cattle (Abdel-Shafy et al., 2014). In the present study, several significant SNP in this region, including BovineHD0600024162: rs134391498, are located within the intronic region of the gene solute carrier family 4 (sodium bicarbonate cotransporter), member 4 (SLCA4A4). This gene has been reported as a candidate gene associated with mastitis susceptibility in Danish Holstein cattle (Wu et al., 2015). Cole and Null (2009) and Appuhamy et al. (2009) reported nega- tive genetic correlations between clinical mastitis (after $100 \mathrm{~d}$ in milk) and persistency of yield traits (milk, fat, and protein yields) in different cattle breeds. They indicated that an increase in persistency of milk, fat, and protein yield traits is associated with decreases in persistency of somatic cell score; SCS is an indicator of clinical and subclinical mastitis in dairy cattle (Appuhamy et al., 2009; Cole and Null, 2009). This result suggests that identified SNP at $88 \mathrm{Mb}$ on BTA6 might influence udder disease susceptibility and subsequently LP in dairy cattle.

Another major signal for LP in the present study was identified on BTA13 at 54 to $55 \mathrm{Mb}$ (Supplementary File S1; https://doi.org/10.3168/jds.2016-11770). This region has not been previously reported to be associated with LP in dairy cattle. The SNP in this region (Supplementary File S1) are located within the genes $M Y T 1$, SLC2A4RG, SLC17A9, LAMA5, ADRM1, OSBPL2, and SS18L1. Bionaz and Loor (2008) indicated that expression of $O S B P L 2$ in the mammary gland increases along with that of $S R E B F 1$ and $S R E B F 2$ during lactation. They suggested that this gene might be involved in the regulation of $S R E B F 1$ and coordination of sphingolipid and cholesterol synthesis within the mammary gland in dairy cattle (Bionaz and Loor, 2008).

Kolbehdari et al. (2009) reported a significant SNP on BTA27 at $12 \mathrm{Mb}$ associated with persistency of milk yield. Littlejohn et al. (2014) also reported significant variants on chromosome 27 , associated with the expression of the AGPAT6 gene (at $36 \mathrm{Mb}$ ), that are causally involved in milk fat synthesis and have pleiotropic effects on other milk components (Littlejohn et al., 2014). The SNP associated with the AGPAT6 gene in the Littlejohn et al. (2014) study were not significant in our results, even before adjusting for FDR. However, we detected 5 significant SNP on BTA27 at $41 \mathrm{Mb}$ for LP (Supplementary File S1; https://doi.org/10.3168/ jds.2016-11770) overlapping with the significant SNP found on BTA 27 associated with milk fat percentage by Littlejohn et al. (2014). This region has not been reported to be associated with LP previously, and we speculate this region to be a new region for this trait (Supplementary File S1). One significant SNP in this region (BovineHD2700012022: rs134277881) is located within the thyroid hormone receptor, $\beta$ (THRB) gene. This gene encodes a nuclear hormone receptor for triiodothyronine and mutations in this gene are known to be the cause of generalized thyroid hormone resistance. Thyroid hormones are known for their importance in milk production through stimulation of metabolic rates with other hormones (including endocrine pancreas and adrenal gland cortex; Blum et al., 1983). A positive correlation has been shown between thyroid hormones in 

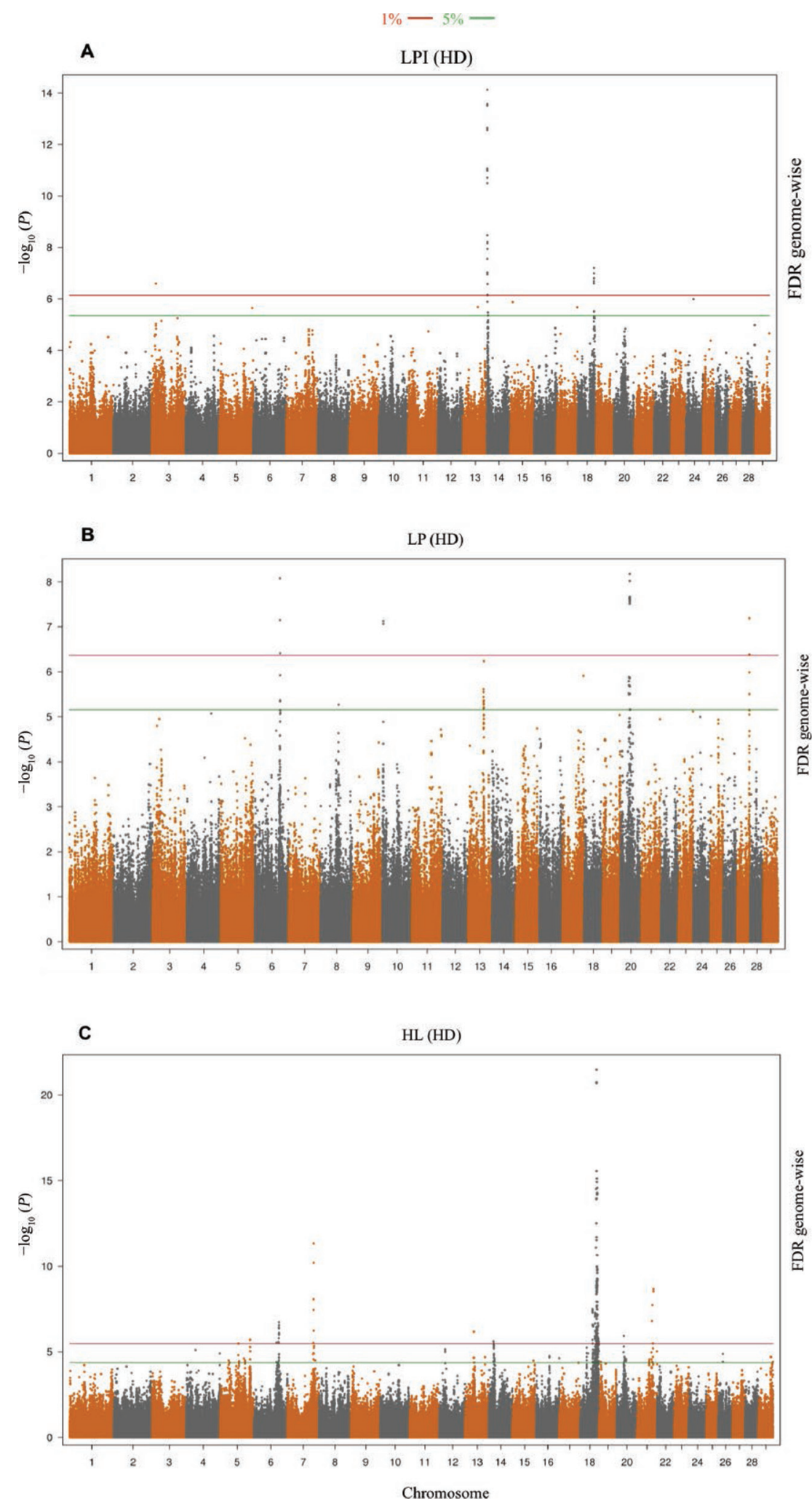

Figure 1. Genome-wide association analysis using single SNP regression mixed linear model for lifetime profit index, lactation persistency, and longevity traits. The $-\log _{10}$ of the $P$-value analysis for association with SNP is plotted. The traits are shown as (A) lifetime profit index (LPI); (B) lactation persistency (LP); (C) herd life (HL); (D) indirect herd life (IHL); and (E) direct herd life (DHL). The black (red) line is the threshold for significant SNP at a 1\% false discovery rate (FDR); the gray (green) line is the threshold for significant SNP at 5\% FDR. HD $=$ high-density SNP panel. Color version available online. 


\section{D}
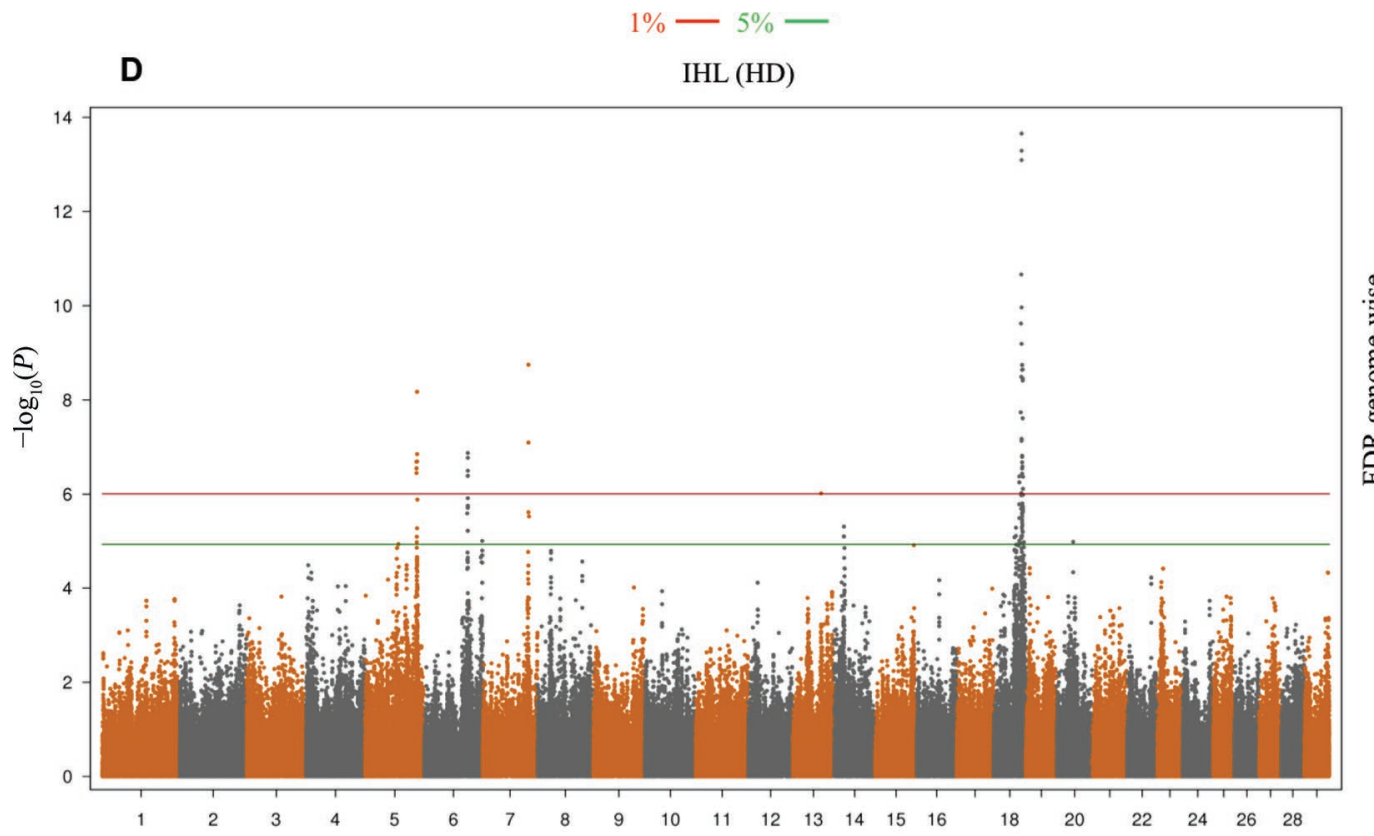

$\mathbf{E}$

DHL (HD)

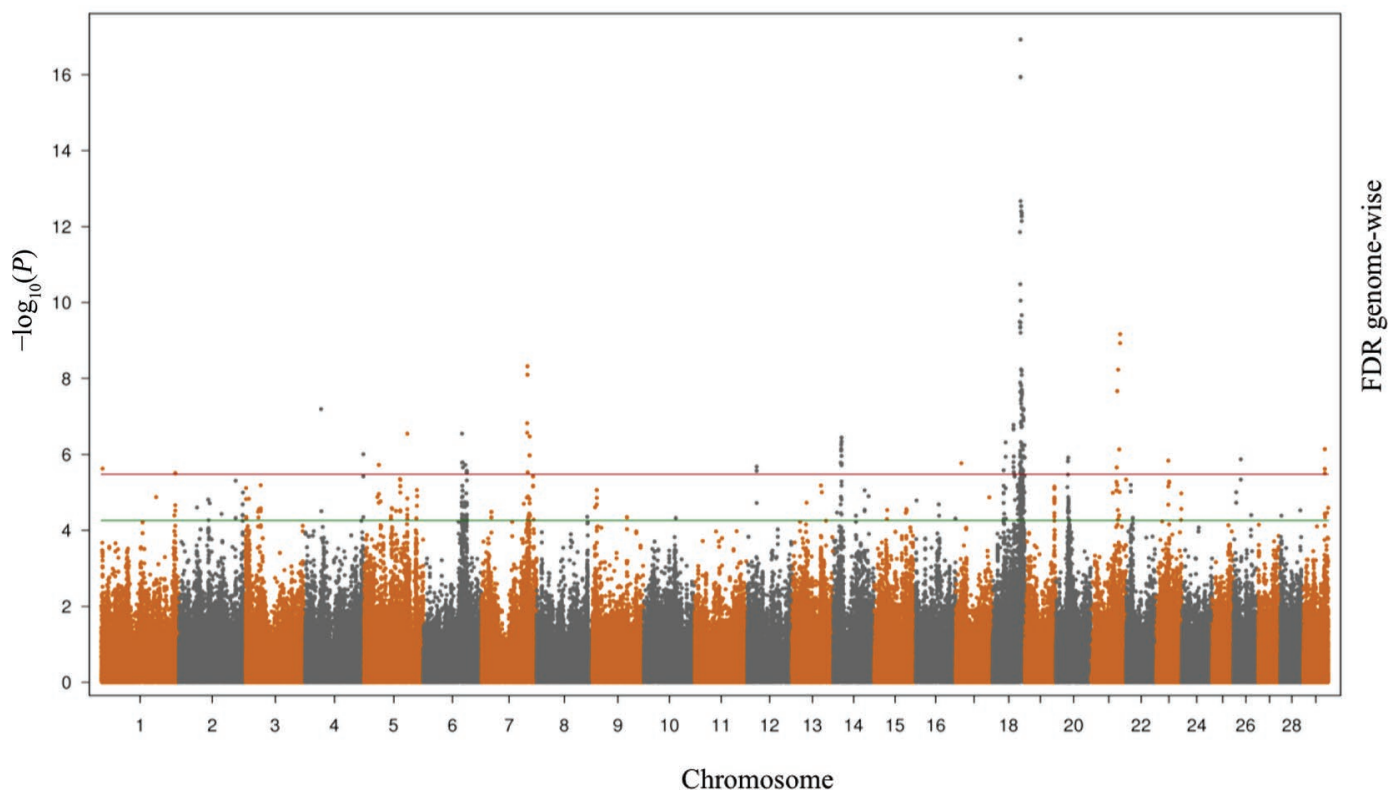

Figure 1 (Continued). Genome-wide association analysis using single SNP regression mixed linear model for lifetime profit index, lactation persistency, and longevity traits. The $-\log _{10}$ of the $P$-value analysis for association with SNP is plotted. The traits are shown as (A) lifetime profit index (LPI); (B) lactation persistency (LP); (C) herd life (HL); (D) indirect herd life (IHL); and (E) direct herd life (DHL). The black (red) line is the threshold for significant SNP at a $1 \%$ false discovery rate (FDR); the gray (green) line is the threshold for significant SNP at $5 \%$ FDR. HD = high-density SNP panel. Color version available online.

blood and energy metabolism (Reist et al., 2002). This proposed gene might be a new potential candidate gene affecting production traits in dairy cattle.

Significant SNP on BTA20 for LP in this study were located at 31 to $32 \mathrm{Mb}$. Several of these, including BovineHD4100014643: rs41639260, ARS-BFGLNGS-118998: rs110482506, and UA-IFASA-7069: rs41639261, are intronic variants residing within the growth hormone receptor $(G H R)$ gene. Association of significant SNP close to the GHR gene with milk fat content was reported in a study on German Holstein cattle (Wang et al., 2012). This region on BTA20 was also in agreement with QTL regions previously identified to be associated with lean meat, carcass yield 

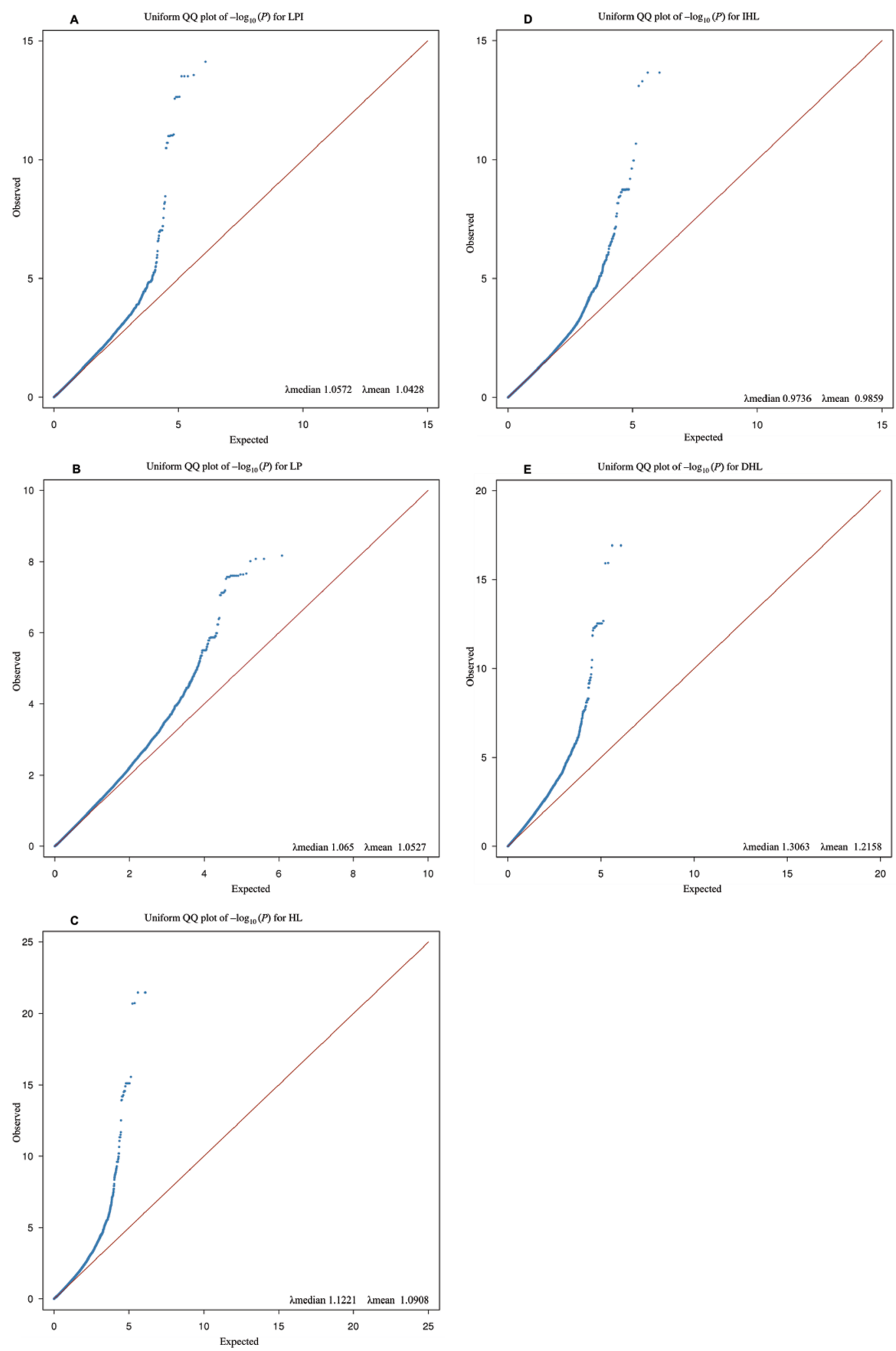

Figure 2. Quantile-quantile (Q-Q) of $P$-values of SNP from single SNP regression mixed linear model for lifetime profit index, lactation persistency, and longevity traits. The Q-Q plots of $P$-values of SNP are shown. The dots (blue) represent the $-\log _{10}(P$-values) to the expected distribution under the null hypothesis of no association. The traits are shown as (A) lifetime profit index (LPI); (B) lactation persistency (LP); (C) herd life (HL); (D) indirect herd life (IHL); and (E) direct herd life (DHL). The line (red) denotes the expected pattern under the null hypothesis. Deviations between the line and dots indicate how the test statistics of loci deviate from the null hypothesis. Color version available online. 
(Doran et al., 2014), and sire conception rate (Li et al., 2012) in Holstein cattle (Supplementary File S2; https://doi.org/10.3168/jds.2016-11770).

The current study also revealed 1 significant SNP (5\% FDR) on chromosome 17 at $72 \mathrm{Mb}$. Boichard et al. (2003) also reported a significant QTL associated with milk persistency (close to marker CSSM033) on chromosome 17. However, the position of that QTL was at $56 \mathrm{Mb}$ (Boichard et al., 2003), which is different from the result found in the present study.

\section{Longevity-Related Traits}

Longevity is a highly desirable trait in the dairy cattle industry that affects overall profitability (Sewalem et al., 2008). This trait is determined by voluntary and involuntary culling decisions based on production, health, fertility, and other functional traits (VanRaden and Wiggans, 1995; Sewalem et al., 2008). Genetic evaluation of longevity for proof bulls is based on herdlife evaluations that reflect the additional number of lactations that daughters of these bulls are expected to have due to reduced culling for nonproduction reasons (www.cdn.ca). Genetic evaluations and analysis of herd life for bulls are based on 2 evaluations: direct herd life (DHL) and indirect herd life (IHL). One of the components of direct herd life is daughter survival in the herd at 5 specific points during their productive life. These 5 measurements of daughter survival are intercorrelated and are used to compute an overall bull proof for direct herd life. Indirect herd life value is calculated based on a function of proof for other nonproduction traits including conformation traits, reproduction traits and udder health traits.

$\boldsymbol{H L}$ and $\boldsymbol{I H L}$. The GWAS identified several significant regions on BTA5, 6, 7, 14, 18, 20 and 21 for HL, with the greatest number of significant SNP on BTA6 and 18 (Figure 1C; Supplementary File S1; https:// doi.org/10.3168/jds.2016-11770). Likewise, the GWAS detected significant SNP (genome-wise FDR 5\%) on BTA5, 6, and 18 associated with IHL (Figure 1D; Supplementary File S1). The corresponding Q-Q plots for HL and IHL are shown in Figure 2C and Figure 2D, respectively. Only a minor and acceptable deviation was found $\left(\lambda_{\text {median }}=0.9736\right)$ for IHL, but a stronger deviation was observed for HL $\left(\lambda_{\text {median }}=1.1221\right)$, indicating some inflation of the statistical tests.

The most significant SNP for HL and IHL were located on BTA18 at 42 to $65 \mathrm{Mb}$ (Supplementary File S1; https://doi.org/10.3168/jds.2016-11770). The location of several highly significant SNP on BTA18 in the present study (BovineHD1800016754: rs135253383, BovineHD1800016606: rs137554975 and BovineHD1800016612: rs136113894) is in agreement with QTL associated with direct calving (fertilityassociated trait) on BTA18 at $57.12 \mathrm{Mb}$, for both HL and IHL (Sahana et al., 2011; Höglund et al., 2012). Additionally, our study identified a significant intronic SNP (BovineHD1800016754: rs135253383) in the cytosolic thiouridylase subunit 1 (CTU1) gene. It has been reported that a missense mutation in the $C T U 1$ gene is the most likely candidate variant for direct calving difficulty in the Holstein-Friesian cattle population (Purfield et al., 2015). Calving ease is a fertility-associated trait. Fertility and postpartum performance of replacement heifers are important traits to minimize the nonproductive period of an animal's life (Akanno et al., 2015).

In another genome scan study carried out on economically important traits in Holstein cattle by Daetwyler et al. (2008) using a linkage disequilibrium single-locus regression model, several QTL were identified on BTA6 (at $84 \mathrm{cM} / 82 \mathrm{Mb}$ ) and BTA13 (at $63 \mathrm{cM} / 50 \mathrm{Mb}$ ) associated with HL. The SNP identified in our study on BTA6 (for both HL and IHL) are located at $88 \mathrm{Mb}$. Furthermore, the significant SNP on BTA13 in our analysis were mostly localized at $30 \mathrm{Mb}$. We also identified several SNP on BTA6 at $88 \mathrm{Mb}$ within the confidence intervals of QTL associated with SCS (AbdelShafy et al., 2014), milk yield, and BCS (Veerkamp et al., 2012) in the Holstein cattle breed (Supplementary File S2; https://doi.org/10.3168/jds.2016-11770). One other highly significant SNP on this chromosome for both HL and IHL (BovineHD0600024403: rs110432804) was assigned to the intron of the gene neuropeptide FF receptor 2 (NPFFR2). This gene has been reported as a candidate gene for udder health and susceptibility to mastitis in Danish Holstein cattle (Wu et al., 2015).

Most of the significant SNP that we found for these 2 traits were located within QTL regions that have been previously reported to be associated with calving traits (calving ease, calf size, stillbirth), clinical mastitis, milk yield, and conformation traits in Holstein and other cattle breeds (Supplementary File S2; https://doi. org/10.3168/jds.2016-11770). Because IHL evaluations are based on a combination of fertility, conformation, and udder health traits, it is very possible that these regions and associated candidate genes, particularly on BTA6 and 18, influence this trait.

DHL. Genome-wide association analysis for DHL detected significant peaks on BTA6, 7, 14, 18, 20, and 21 (Figure 1E). The deviation of the observed $P$-values from the expected distribution, under the null hypothesis, for DHL is depicted in (Figure 2E) and it shows substantial deviation from $1\left(\lambda_{\text {median }}=1.3063\right)$, indicating some inflation of the statistical tests. The most significant SNP (genome-wise FDR 1\%) are shown in Supplementary File S1 (https://doi.org/10.3168/ 

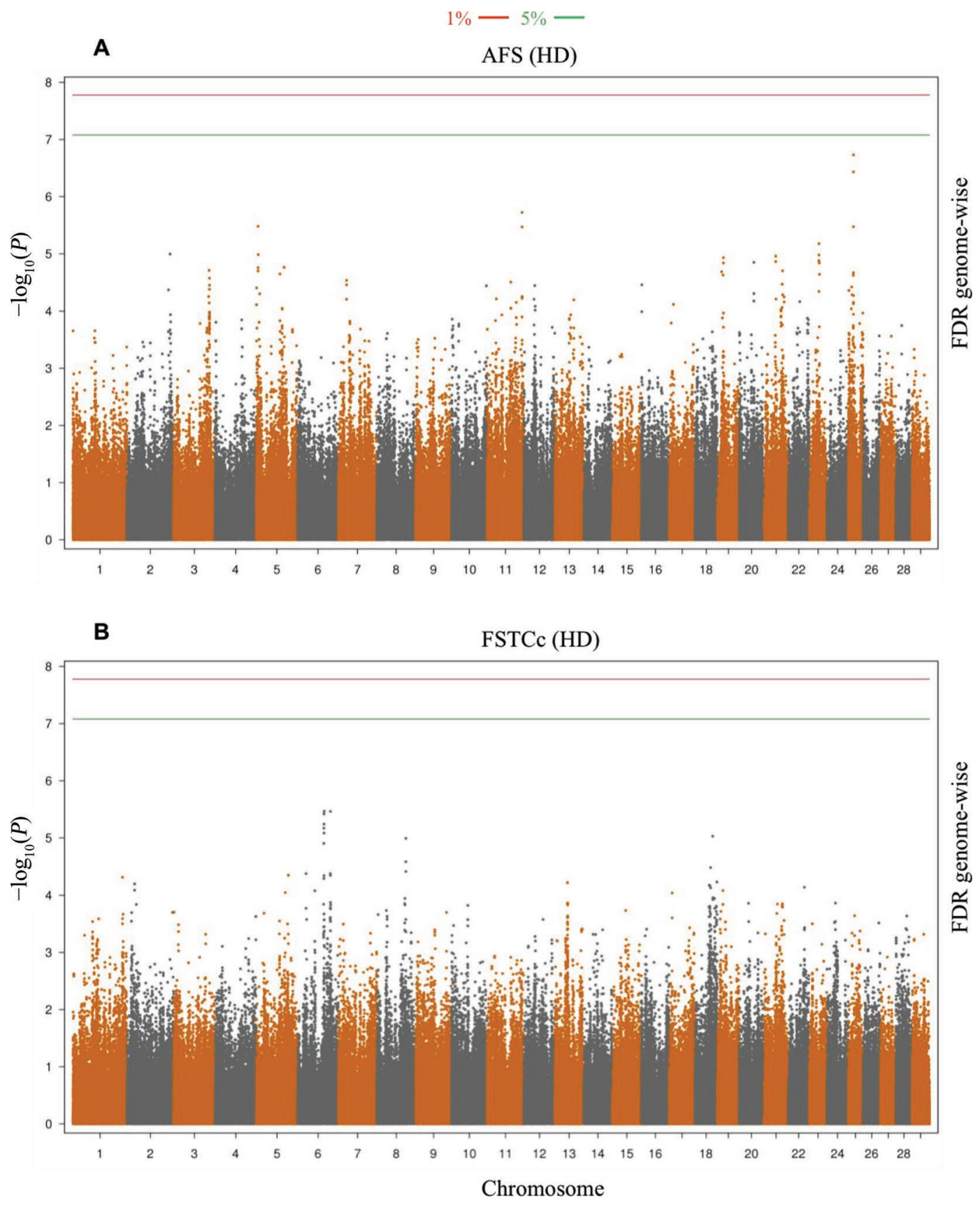

Figure 3. Genome-wide association analysis using single SNP regression mixed linear model for fertility-associated traits. The $-\log _{10}$ of the $P$-value analysis for association with SNP is plotted. The traits are shown as (A) age at first service (AFS); (B) cow first service to conception (FSTCc); (C) cow nonreturn rate (NRRc); and (D) heifer nonreturn rate (NRRh). The black (red) line is the threshold for significant SNP at a $1 \%$ false discovery rate (FDR); the gray (green) line is the threshold for significant SNP at 5\% FDR. HD = high-density SNP panel. Color version available online.

jds.2016-11770). One significant peak on BTA18 at 52 to $60 \mathrm{Mb}$ overlaps among DHL, HL, and IHL in this study. This region on BTA18 with the highest number of significant SNP (258 SNP) for DHL was close to the significant QTL found by Cole and Null (2009) at 57 $\mathrm{Mb}$ and Kolbehdari et al. (2009) at $53 \mathrm{Mb}$ associated with calf growth rate, conformation, calving ease, and fertility traits in Canadian Holsteins. We further investigated the position of these significant SNP relative to previously known QTL. The result indicated that several SNP were located within the confidence interval of QTL associated with SCS (Brand et al., 2009), disease 

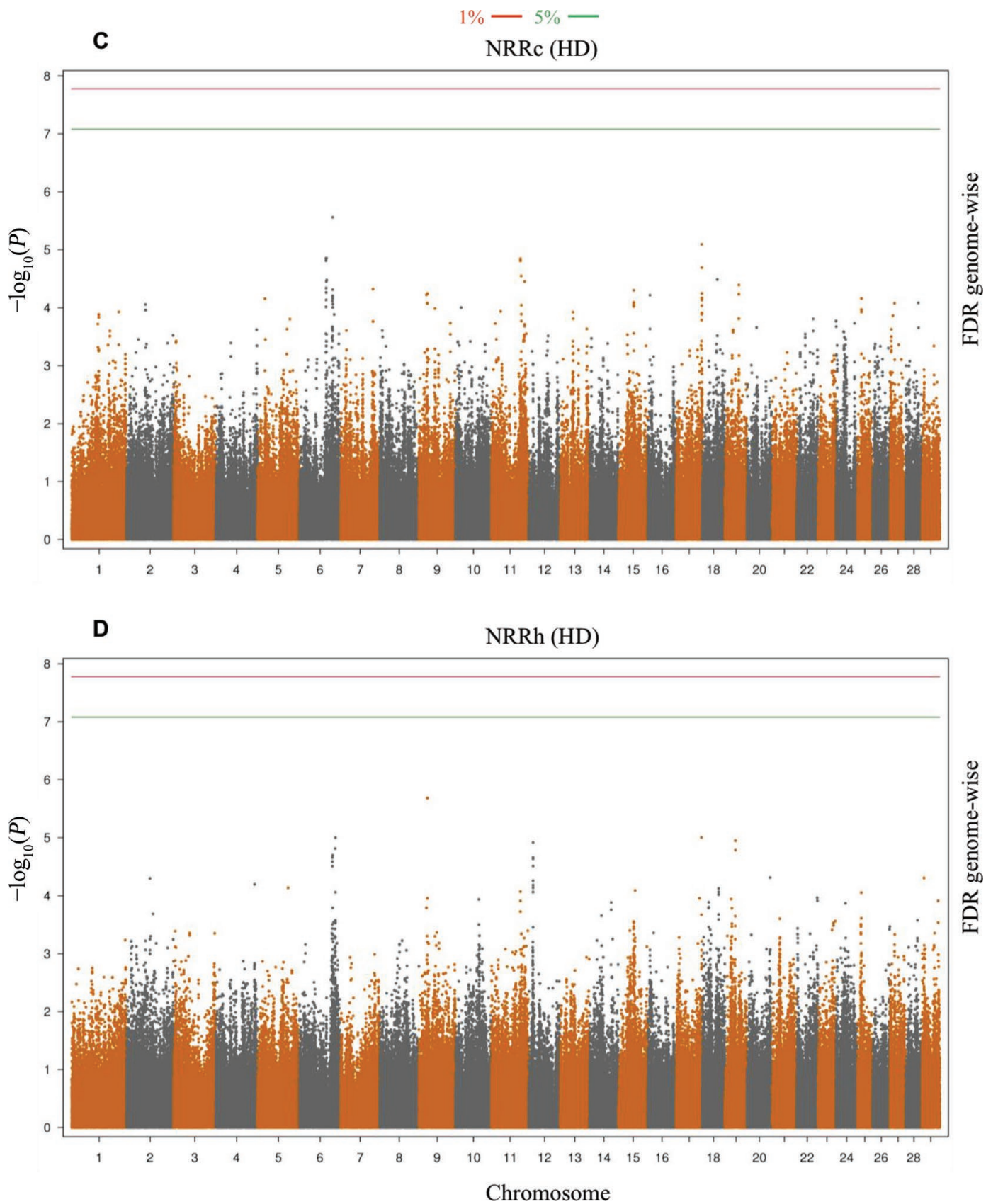

Figure 3 (Continued). Genome-wide association analysis using single SNP regression mixed linear model for fertility-associated traits. The $-\log _{10}$ of the $P$-value analysis for association with SNP is plotted. The traits are shown as (A) age at first service (AFS); (B) cow first service to conception (FSTCc); (C) cow nonreturn rate (NRRc); and (D) heifer nonreturn rate (NRRh). The black (red) line is the threshold for significant SNP at a $1 \%$ false discovery rate (FDR); the gray (green) line is the threshold for significant SNP at $5 \%$ FDR. HD $=$ high-density SNP panel. Color version available online.

susceptibility (Mycobacterium avium ssp. paratuberculosis susceptibility; Pant et al., 2011), and calvingassociated traits (Schulman et al., 2011; Höglund et al., 2012) on BTA18 in Holstein cattle (Supplementary File S2; https://doi.org/10.3168/jds.2016-11770).

The position of a significant SNP on BTA13 (BovineHD1300016998: rs110323780) at $59 \mathrm{Mb}$ was in agreement with significant SNP within a QTL identified in a previous study that was associated with HL (Daetwyler et al., 2008). This location also overlaps with the position of a QTL found to be associated with calving ease, calf size, and stillbirth in Holstein dairy cattle (Höglund et al., 2012). Additionally, the location of the highly significant SNP on BTA21 in our study is 
consistent with a QTL associated with SCS in Norwegian Red cattle (Sodeland et al., 2011; Supplementary File S2; https://doi.org/10.3168/jds.2016-11770).

Somatic cell score is an indicator of udder health and is highly correlated with clinical mastitis (Brand et al., 2009). Short and Lawlor (1992) reported that udder traits have large absolute genetic correlations with herd-life traits. Furthermore, increased susceptibility to disease is one of the main factors of reduced productivity, premature culling, and mortality (Pant et al., 2011). Taken together with these previous results, our findings indicate that these regions and significant SNP may have an effect on longevity in dairy cattle and may be used for further genomic prediction analysis to identify causal candidate variants that affect herd-life traits.

\section{Female Fertility Traits}

Several studies have investigated genomic regions associated with puberty-associated traits such as AFS and NRR after first service in heifers and cows in Nordic Holstein, Nordic Red, Jersey, German Holstein, Finnish Ayrshire, Swedish and Italian Holstein cattle (Kühn et al., 2003; Holmberg and Andersson-Eklund, 2006; Höglund et al., 2009; Schulman et al., 2011; Minozzi et al., 2013; Höglund et al., 2014b, 2015). One study reported 3 QTL associated with age at puberty in Brahman and tropical-adapted beef cattle on BTA1 (Hawken et al., 2012). Several SNP were found to be associated with AFS on BTA1 and BTA2 in Chinese and North American Holstein cattle (Daetwyler et al., 2008; Hyeong et al., 2014). However, we did not find any associations with AFS in the present study (Figure 3A). Quantitative trait loci were also reported for NRR in cows and heifers on several chromosomes, including BTA1, 4, 5, 9, 11, and 13 in Nordic Red, Jersey, Danish, Swedish, and Ayrshire dairy cattle (Höglund et al., 2009, 2014a, 2015; Schulman et al., 2011). In Brangus cattle, one significant SNP was associated with interval from first service to conception (Peters et al., 2013). This region on BTA26 was also found to be associated with age at first calving in another recent study (Hyeong et al., 2014). No associated regions were identified for the FSTCc, NRRc, and NRRh traits in the present study (Figure 3B-D). We can speculate that the absence of significant associations for these traits is a consequence of their low heritability (4 to 5\%) and their highly polygenic nature.

\section{CONCLUSIONS}

The present GWAS identified SNP associated with lactation persistency, longevity, and lifetime profit index in Holstein dairy cattle. However, no associations could be identified for female fertility traits. The strongest associations were detected on BTA14 and BTA18 for lifetime profit index and on BTA6 and BTA20 for lactation persistency. In addition, 2 novel regions associated with lactation persistency were identified on BTA13 and BTA27. These regions contain several candidate genes, including $M Y T 1, S L C 2 A 4 R G$, and SLC17A9 on BTA13 and THRB on BTA27. The most significant SNP associated with longevity traits were found on BTA18 and were mostly located within known QTL regions associated with mastitis and calving-associated traits. In summary, these results can be used to identify candidate genes and casual mutations that might help to increase the accuracy of genomic selection and provide mechanistic insight into traits.

\section{ACKNOWLEDGMENTS}

The authors acknowledge the financial contributions of L'Alliance Boviteq (LAB, Guelph, Ontario, Canada) and the Natural Sciences and Engineering Research Council (NSERC) of Ottawa, Ontario, Canada. We thank the Canadian Dairy Network, Guelph, Ontario, Canada, for providing some of the data used in this study.

\section{REFERENCES}

Abdel-Shafy, H., R. H. Bortfeldt, M. Reissmann, and G. A. Brockmann. 2014. Short communication: Validation of somatic cell score-associated loci identified in a genome-wide association study in German Holstein cattle. J. Dairy Sci. 97:2481-2486. https://doi. org/10.3168/jds.2013-7149.

Akanno, E. C., G. Plastow, C. Fitzsimmons, S. P. Miller, V. Baron, K. Ominski, and J. A. Basarab. 2015. Genome-wide association for heifer reproduction and calf performance traits in beef cattle. Genome 58:549-557. https://doi.org/10.1139/gen-2015-0031.

Appuhamy, J. A. D. R. N., B. G. Cassell, and J. B. Cole. 2009. Phenotypic and genetic relationships of common health disorders with milk and fat yield persistencies from producer-recorded health data and test-day yields. J. Dairy Sci. 92:1785-1795. https://doi. org/10.3168/jds.2008-1591.

Ashwell, M. S., D. W. Heyen, T. S. Sonstegard, C. P. Van Tassell, Y. Da, P. M. VanRaden, M. Ron, J. I. Weller, and H. A. Lewin. 2004. Detection of quantitative trait loci affecting milk production, health, and reproductive traits in Holstein cattle. J. Dairy Sci. 87:468-475. https://doi.org/10.3168/jds.S0022-0302(04)73186-0.

Bionaz, M., and J. J. Loor. 2008. Gene networks driving bovine milk fat synthesis during the lactation cycle. BMC Genomics 9:366. https://doi.org/10.1186/1471-2164-9-366.

Blum, J. W., P. Kunz, H. Leuenberger, K. Gautschi, and M. Keller. 1983. Thyroid hormones, blood plasma metabolites and haematological parameters in relationship to milk yield in dairy cows. Anim. Prod. 36:93-104. https://doi.org/10.1017/S0003356100039982.

Boichard, D. 1990. Estimation of the economic value of conception rate in dairy cattle. Livest. Prod. Sci. 24:187-204. https://doi. org/10.1016/0301-6226(90)90001-M.

Boichard, D. B., C. Grohs, F. Bourgeois, F. Cerqueira, R. Faugeras, A. Neau, R. Rupp, Y. Amigues, M. Y. Boscher, and H. Leveziel. 2003. Detection of genes influencing economic traits in three 
French dairy cattle breeds. Genet. Sel. Evol. 35:77-101. https:// doi.org/10.1051/gse:2002037.

Brand, B., C. Baes, M. Mayer, N. Reinsch, and C. Kühn. 2009. Identification of a two-marker-haplotype on Bos taurus autosome 18 associated with somatic cell score in German Holstein cattle. BMC Genet. 10:50 https://doi.org/10.1186/1471-2156-10-50.

Buitenhuis, B., L. L. Janss, N. A. Poulsen, L. B. Larsen, M. K. Larsen, and P. Sørensen. 2014. Genome-wide association and biological pathway analysis for milk-fat composition in Danish Holstein and Danish Jersey cattle. BMC Genomics 15:1112 https://doi. org /10.1186/1471-2164-15-1112.

Cole, J. B., and D. J. Null. 2009. Genetic evaluation of lactation persistency for five breeds of dairy cattle. J. Dairy Sci. 92:2248-2258. https://doi.org/10.3168/jds.2008-1825.

Conte, G., M. Mele, S. Chessa, B. Castiglioni, A. Serra, G. Pagnacco, and P. Secchiari. 2010. Diacylglycerol acyltransferase 1, stearoylCoA desaturase 1 , and sterol regulatory element binding protein 1 gene polymorphisms and milk fatty acid composition in Italian Brown cattle. J. Dairy Sci. 93:753-763. https://doi.org/10.3168/ jds.2009-2581.

Daetwyler, H. D., F. S. Schenkel, M. Sargolzaei, and J. A. B. Robinson. 2008. A genome scan to detect quantitative trait loci for economically important traits in Holstein cattle using two methods and a dense single nucleotide polymorphism map. J. Dairy Sci. 91:3225-3236. https://doi.org/10.3168/jds.2007-0333.

Devlin, B., and K. Roeder. 1999. Genomic control for association studies. Biometrics 55:997-1004. https://doi.org/10.1111/j.0006341X.1999.00997.x.

Doran, A. G., D. P. Berry, and C. J. Creevey. 2014. Whole genome association study identifies regions of the bovine genome and biological pathways involved in carcass trait performance in Holstein-Friesian cattle. BMC Genomics 15:837 https://doi. org/10.1186/1471-2164-15-837.

Garcia, M. D., J. J. Michal, C. T. Gaskins, J. J. Reeves, T. L. Ott, Y. Liu, and Z. Jiang. 2006. Significant association of the calpastatin gene with fertility and longevity in dairy cattle. Anim. Genet. 37:304-305. https://doi.org/10.1111/j.1365-2052.2006.01443.x.

Grisart, B., W. Coppieters, F. Farnir, L. Karim, and C. Ford. 2002. Positional candidate cloning of a QTL in dairy cattle: Identification of a missense mutation in the bovine DGAT gene with major effect on milk yield and composition. Genome Res. 12:222-231. https://doi.org/10.1101/gr.224202.

Harder, B., J. Bennewitz, N. Reinsch, G. Thaller, H. Thomsen, C. Kühn, M. Schwerin, G. Erhardt, M. Förster, F. Reinhardt, and E. Kalm. 2006. Mapping of quantitative trait loci for lactation persistency traits in German Holstein dairy cattle. J. Anim. Breed. Genet. 123:89-96. https://doi.org/10.1111/j.1439-0388.2006.00577.x.

Hawken, R. J., Y. D. Zhang, M. R. S. Fortes, E. Collis, W. C. Barris, N. J. Corbet, P. J. Williams, G. Fordyce, R. G. Holroyd, J. R. W Walkley, W. Barendse, D. J. Johnston, K. C. Prayaga, B. Tier, A. Reverter, and S. A. Lehnert. 2012. Genome-wide association studies of female reproduction in tropically adapted beef cattle. J. Anim. Sci. 90:1398-1410. https://doi.org/10.2527/jas.2011-4410.

Höglund, J. K., B. Buitenhuis, B. Guldbrandtsen, M. S. Lund, and G. Sahana. 2015. Genome-wide association study for female fertility in Nordic Red cattle. BMC Genet. 16:110 https://doi.org/10.1186/ s12863-015-0269-x.

Höglund, J. K., B. Guldbrandtsen, M. S. Lund, and G. Sahana. 2012. Analyzes of genome-wide association follow-up study for calving traits in dairy cattle. BMC Genet. 13:71 https://doi. org/10.1186/1471-2156-13-71.

Höglund, J. K., B. Guldbrandtsen, G. Su, B. Thomsen, and M. S. Lund. 2009. Genome scan detects quantitative trait loci affecting female fertility traits in Danish and Swedish Holstein cattle. J. Dairy Sci. 92:2136-2143. https://doi.org/10.3168/jds.2008-1104.

Höglund, J. K., G. Sahana, R. F. Brøndum, B. Guldbrandtsen, B. Buitenhuis, and M. S. Lund. 2014a. Fine mapping QTL for female fertility on BTA04 and BTA13 in dairy cattle using HD SNP and sequence data. BMC Genomics 15:790 https://doi. org/10.1186/1471-2164-15-790.
Höglund, J. K., G. Sahana, B. Guldbrandtsen, and M. S. Lund. 2014b. Validation of associations for female fertility traits in Nordic Holstein, Nordic Red and Jersey dairy cattle. BMC Genet. 15:8 https://doi.org/10.1186/1471-2156-15-8.

Holmberg, M., and L. Andersson-Eklund. 2006. Quantitative trait loci affecting fertility and calving traits in Swedish dairy cattle. J. Dairy Sci. 89:3664-3671. https://doi.org/10.3168/jds.S00220302(06)72406-7.

Hyeong, K. E., A. Iqbal, A. Iqbal, and J. J. Kim. 2014. A genome wide association study on age at first calving using high density single nucleotide polymorphism chips in Hanwoo (Bos taurus coreanae). Asian-australas. J. Anim. Sci. 27:1406-1410. https:// doi.org/10.5713/ajas.2014.14273.

Jiang, L., X. Liu, J. Yang, H. Wang, J. Jiang, L. Liu, S. He, X. Ding, J. Liu, and Q. Zhang. 2014. Targeted resequencing of GWAS loci reveals novel genetic variants for milk production traits. BMC Genomics 15:1105 https://doi.org/10.1186/1471-2164-15-1105.

Kadarmideen, H. N., R. Thompson, and G. Simm. 2000. Linear and threshold model genetic parameters for disease, fertility and milk production in dairy cattle. Anim. Sci. 71:411-419.

Kolbehdari, D., Z. Wang, J. R. Grant, B. Murdoch, A. Prasad, Z. Xiu, E. Marques, P. Stothard, and S. S. Moore. 2009. A whole genome scan to map QTL for milk production traits and somatic cell score in Canadian Holstein bulls. J. Anim. Breed. Genet. 126:216-227. https://doi.org/10.1111/j.1439-0388.2008.00793.x.

Kühn, C., J. Bennewitz, N. Reinsch, N. Xu, H. Thomsen, C. Looft, G. A. Brockmann, M. Schwerin, C. Weimann, S. Hiendleder, G. Erhardt, I. Medjugorac, M. Fo, B. Brenig, F. Reinhardt, R. Reents, I. Russ, G. Averdunk, J. Blu, and E. Kalm. 2003. Quantitative Trait Loci Mapping of Functional Traits in the German Holstein Cattle Population. J. Dairy Sci. 86:360-368. https://doi.org/10.3168/jds. S0022-0302(03)73614-5.

Kulak, K. K., J. C. M. Dekkers, A. J. McAllister, and A. J. Lee. 1997. Relationships of early performance traits to lifetime profitability in Holstein cows. Can. J. Anim. Sci. 77:617-624. https:// doi.org/10.4141/A96-129.

Li, G., F. Peñagaricano, K. A. Weigel, Y. Zhang, G. Rosa, and H. Khatib. 2012. Comparative genomics between fly, mouse, and cattle identifies genes associated with sire conception rate. J. Dairy Sci. 95:6122-6129. https://doi.org/10.3168/jds.2012-5591.

Littlejohn, M. D., K. Tiplady, T. Lopdell, T. A. Law, A. Scott, C. Harland, R. Sherlock, K. Henty, V. Obolonkin, K. Lehnert, A. Macgibbon, R. J. Spelman, S. R. Davis, and R. G. Snell. 2014. Expression variants of the lipogenic AGPAT6 gene affect diverse milk composition phenotypes in Bos taurus. PLoS One 9:e85757 https://doi.org/10.1371/journal.pone.0085757.

Minozzi, G., E. L. Nicolazzi, A. Stella, S. Biffani, R. Negrini, B. Lazzari, P. Ajmone-Marsan, and J. L. Williams. 2013. Genome wide analysis of fertility and production traits in Italian Holstein cattle. PLoS One 8:e80219 https://doi.org/10.1371/journal.pone.0080219.

Nemcova, E., M. Stipkova, L. Zavadilova, J. Bouska, and M. Vacek. 2007. The relationship between somatic cell count, milk production and six linearly scored type traits in Holstein cows. Czech J. Anim. Sci. 52:437-446.

Oltenacu, P. A., and B. Algers. 2005. Selection for increased production and the welfare of dairy cows: Are new breeding goals needed? Ambio A J. Hum. Environ. 34:311-315.

Pant, S. D., C. P. Verschoor, F. S. Schenkel, Q. You, D. F. Kelton, and N. A. Karrow. 2011. Bovine PGLYRP1 polymorphisms and their association with resistance to Mycobacterium avium ssp. paratuberculosis. Anim. Genet. 42:354-360. https://doi.org/10.1111/j.13652052.2010.02153.x.

Peñagaricano, F., K. A. Weigel, and H. Khatib. 2012. Genome-wide association study identifies candidate markers for bull fertility in Holstein dairy cattle. Anim. Genet. 43:65-71. https://doi. org/10.1111/j.1365-2052.2012.02350.x.

Peters, S. O., K. Kizilkaya, D. J. Garrick, R. L. Fernando, J. M. Reecy, R. L. Weaber, G. A. Silver, and M. G. Thomas. 2013. Heritability and Bayesian genome-wide association study of first service conception and pregnancy in Brangus heifers. J. Anim. Sci. 91:605-612. https://doi.org/10.2527/jas.2012-5580. 
Pryce, J. E., M. Haile-Mariam, K. Verbyla, P. J. Bowman, M. E. Goddard, and B. J. Hayes. 2010. Genetic markers for lactation persistency in primiparous Australian dairy cows. J. Dairy Sci. 93:2202-2214. https://doi.org/10.3168/jds.2009-2666.

Purfield, D. C., D. G. Bradley, R. D. Evans, F. J. Kearney, and D. P. Berry. 2015. Genome-wide association study for calving performance using high-density genotypes in dairy and beef cattle. Genet. Sel. Evol. 47:47 https://doi.org/10.1186/s12711-015-0126-4.

Reist, M., D. Erdin, D. von Euw, K. Tschuemperlin, H. Leuenberger, Y. Chilliard, H. M. Hammon, C. Morel, C. Philipona, Y. Zbinden, N. Kuenzi, and J. W. Blum. 2002. Estimation of energy balance at the individual and herd level using blood and milk traits in high-yielding dairy cows. J. Dairy Sci. 85:3314-3327. https://doi. org/10.3168/jds.S0022-0302(02)74420-2.

Royal, M. D., A. P. F. Flint, and J. A. Woolliams. 2002. Genetic and phenotypic relationships among endocrine and traditional fertility traits and production traits in Holstein-Friesian dairy cows. J. Dairy Sci. 85:958-967. https://doi.org/10.3168/jds.S00220302(02)74155-6.

Sahana, G., B. Guldbrandtsen, and M. S. Lund. 2011. Genome-wide association study for calving traits in Danish and Swedish Holstein cattle. J. Dairy Sci. 94:479-486. https://doi.org/10.3168/jds.20103381.

Sahana, G., B. Guldbrandtsen, B. Thomsen, and M. S. Lund. 2013. Confirmation and fine-mapping of clinical mastitis and somatic cell score QTL in Nordic Holstein cattle. Anim. Genet. 44:620-626. https://doi.org/10.1111/age.12053.

Sargolzaei, M. 2014. SNP1101 User's Guide. Version 1.0.0. Mehdi Sargolzaei, Semex Alliance, Ontario, Canada.

Sargolzaei, M., J. P. Chesnais, and F. S. Schenkel. 2014. A new approach for efficient genotype imputation using information from relatives. BMC Genomics 15:478 https://doi.org/10.1186/14712164-15-478.

Schennink, A., J. M. L. Heck, H. Bovenhuis, M. H. P. W. Visker, H. J. F. Van Valenberg, and J. A. M. Van Arendonk. 2008. Milk fatty acid unsaturation: Genetic parameters and effects of stearoyl-CoA desaturase (SCD1) and acyl CoA:diacylglycerol acyltransferase 1 (DGAT1). J. Dairy Sci. 91:2135-2143. https://doi.org/10.3168/ jds.2007-0825.

Schennink, A., W. M. Stoop, M. H. P. W. Visker, J. M. L. Heck, H. Bovenhuis, J. J. Van Der Poel, H. J. F. Van Valenberg, and J. A M. Van Arendonk. 2007. DGAT1 underlies large genetic variation in milk-fat composition of dairy cows. Anim. Genet. 38:467-473. https://doi.org/10.1111/j.1365-2052.2007.01635.x.

Schulman, N. F., G. Sahana, T. Iso-Touru, S. D. McKay, R. D. Schnabel, M. S. Lund, J. F. Taylor, J. Virta, and J. H. Vilkki. 2011. Mapping of fertility traits in Finnish Ayrshire by genomewide association analysis. Anim. Genet. 42:263-269. https://doi. org/10.1111/j.1365-2052.2010.02149.x.

Sciascia, Q., D. Pacheco, and S. A. McCoard. 2013. Increased milk protein synthesis in response to exogenous growth hormone is associated with changes in mechanistic (mammalian) target of rapamycin (mTOR)C1-dependent and independent cell signaling. J. Dairy Sci. 96:2327-2338. https://doi.org/10.3168/jds.2012-6267.

Sewalem, A., F. Miglior, G. J. Kistemaker, P. Sullivan, and B. J. Van Doormaal. 2008. Relationship between reproduction traits and functional longevity in Canadian dairy cattle. J. Dairy Sci. 91:1660-1668. https://doi.org/10.3168/jds.2007-0178.
Shook, G. E. 2006. Major advances in determining appropriate selection goals. J. Dairy Sci. 89:1349-1361. https://doi.org/10.3168/ jds.S0022-0302(06)72202-0.

Short, T. H., and T. J. Lawlor. 1992. Genetic parameters of conformation traits, milk yield, and herd life in Holsteins. J. Dairy Sci 75:1987-1998. https://doi.org/10.3168/jds.S0022-0302(92)77958-

Sodeland, M., M. P. Kent, H. G. Olsen, M. A. Opsal, M. Svendsen, E. Sehested, B. J. Hayes, and S. Lien. 2011. Quantitative trait loci for clinical mastitis on chromosomes 2, 6, 14 and 20 in Norwegian Red cattle. Anim. Genet. 42:457-465. https://doi.org/10.1111/j.13652052.2010.02165.x.

VanRaden, P. M. 2004. Invited review: Selection on net merit to improve lifetime profit. J. Dairy Sci. 87:3125-3131. https://doi. org/10.3168/jds.S0022-0302(04)73447-5.

VanRaden, P. M. 2008. Efficient methods to compute genomic predictions. J. Dairy Sci. 91:4414-4423. https://doi.org/10.3168/ jds.2007-0980.

VanRaden, P. M., C. P. Van Tassell, G. R. Wiggans, T. S. Sonstegard, R. D. Schnabel, J. F. Taylor, and F. S. Schenkel. 2009. Invited review: Reliability of genomic predictions for North American Holstein bulls. J. Dairy Sci. 92:16-24. https://doi.org/10.3168/ jds.2008-1514.

VanRaden, P. M., and G. R. Wiggans. 1995. Productive life evaluations: Calculation, accuracy, and economic value. J. Dairy Sci 78:631-638. https://doi.org/10.3168/jds.S0022-0302(95)76674-7.

Veerkamp, R. F., M. P. Coffey, D. P. Berry, Y. de Haas, E. Strandberg, H. Bovenhuis, M. P. L. Calus, and E. Wall. 2012. Genome-wide associations for feed utilisation complex in primiparous HolsteinFriesian dairy cows from experimental research herds in four European countries. Animal 6:1738-1749. https://doi.org/10.1017/ S1751731112001152.

Wang, X., P. Ma, J. Liu, Q. Zhang, Y. Zhang, X. Ding, L. Jiang, Y. Wang, Y. Zhang, D. Sun, S. Zhang, G. Su, and Y. Yu. 2015. Genome-wide association study in Chinese Holstein cows reveal two candidate genes for somatic cell score as an indicator for mastitis susceptibility. BMC Genet. 16:111 https://doi.org/10.1186/ s12863-015-0263-3.

Wang, X., C. Wurmser, H. Pausch, S. Jung, F. Reinhardt, J. Tetens, G. Thaller, and R. Fries. 2012. Identification and dissection of four major QTL affecting milk fat content in the German HolsteinFriesian population. PLoS One 7:e40711 https://doi.org/10.1371/ journal.pone.0040711.

Wickramasinghe, S., S. Hua, G. Rincon, A. Islas-Trejo, J. B. German, C. B. Lebrilla, and J. F. Medrano. 2011. Transcriptome profiling of bovine milk oligosaccharide metabolism genes using RNAsequencing. PLoS One 6:e18895 https://doi.org/10.1371/journal. pone.0018895.

Wiggans, G. R., T. S. Sonstegard, P. M. VanRaden, L. K. Matukumalli, R. D. Schnabel, J. F. Taylor, F. S. Schenkel, and C. P. Van Tassell. 2009. Selection of single-nucleotide polymorphisms and quality of genotypes used in genomic evaluation of dairy cattle in the United States and Canada. J. Dairy Sci. 92:3431-3436. https:// doi.org/10.3168/jds.2008-1758.

Wu, X., M. S. Lund, G. Sahana, B. Guldbrandtsen, D. Sun, Q. Zhang, and G. Su. 2015. Association analysis for udder health based on SNP-panel and sequence data in Danish Holsteins. Genet. Sel. Evol. 47:50 https://doi.org/10.1186/s12711-015-0129-1. 